\title{
Temporal and Spatial Analysis of Flood Occurrences in the Drainage Basin of Pinios River (Thessaly, Central Greece)
}

\author{
George D. Bathrellos ${ }^{1, *(\mathbb{D}}$, Hariklia D. Skilodimou ${ }^{1}$, Konstantinos Soukis ${ }^{2}$ (D) \\ and Efterpi Koskeridou ${ }^{3}$ \\ 1 Department of Geography and Climatology, Faculty of Geology and Geoenvironment, National and \\ Kapodistrian University of Athens, University Campus, ZC. 15784 Zografou, Athens, Greece; \\ hskilodimou@geol.uoa.gr \\ 2 Department of Dynamic Tectonic Applied Geology, Faculty of Geology and Geoenvironment, National and \\ Kapodistrian University of Athens, University Campus, ZC. 15784 Zografou, Athens, Greece; \\ soukis@geol.uoa.gr \\ 3 Department of Historical Geology-Palaeontology, Faculty of Geology and Geoenvironment, National and \\ Kapodistrian University of Athens, University Campus, ZC. 15784 Zografou, Athens, Greece; \\ ekosker@geol.uoa.gr \\ * Correspondence: gbathrellos@geol.uoa.gr; Tel.: +30-210-727-4882
}

Received: 11 August 2018; Accepted: 7 September 2018; Published: 11 September 2018

\begin{abstract}
Historic data and old topographic maps include information on historical floods and paleo-floods. This paper aims at identifying the flood hazard by using historic data in the drainage basin of Pinios (Peneus) River, in Thessaly, central Greece. For this purpose, a catalogue of historical flood events that occurred between 1979 and 2010 and old topographic maps of 1881 were used. Moreover, geomorphic parameters such as elevation, slope, aspect and slope curvature were taken into account. The data were combined with the Geographical Information System to analyze the temporal and spatial distribution of flood events. The results show that a total number of 146 flood events were recorded in the study area. The number of flood events reaches its maximum value in the year 1994, while October contains the most flood events. The flood occurrences increased during the period 1990-2010. The flooded area reaches its maximum value in the year 1987, and November is the month with the most records. The type of damages with the most records is for rural land use. Regarding the class of damages, no human casualties were recorded during the studied period. The annual and monthly distribution of the very high category reaches the maximum values, respectively, in the year 2005 and in June. The analysis of the spatial distribution of the floods proves that most of the occurrences are recorded in the southern part of the study area. There is a certain amount of clustering of flood events in the areas of former marshes and lakes along with the lowest and flattest parts of the study area. These areas are located in the central, southern, south-eastern and coastal part of the study area and create favorable conditions for flooding. The proposed method estimates the localization of sites prone to flood, and it may be used for flood hazard assessment mapping and for flood risk management.
\end{abstract}

Keywords: historic flood data; old topographic maps; GIS; temporal and spatial distribution of flood events; marshy areas and lakes; flood hazard assessment

\section{Introduction}

Natural hazards are physical events that can cause significant damages to the natural and human environment. Endogenic or exogenic processes such as active tectonics and climate changes are 
capable of changing landforms and triggering natural hazards, which in some cases control human activities [1-11].

Floods are physical phenomena active in geological time and the result of excess runoff. When rivers overtop their banks, the excess water goes to the floodplain. Floodplains represent favorable sites for man to settle because they are fertile, level, easy to excavate and near water. These features have contributed to increased development and urbanization of floodplains, thereby increasing the chances of the flood occurrences that cause disasters. Despite the construction of flood control works such as dams, levees and channeling rivers, the flood damage has increased [12-16].

Floods occur frequently in some parts of the world. While for some areas, yearly flooding is necessary to sustain crops, for other areas, flooding spells disaster. Especially, in urban areas, floods are considered among the most dangerous natural hazards due to the increasing number of events. Their consequences are not only environmental, but social and economic, as well, since they may cause damages to urban areas and agricultural lands and may even result in the loss of lives [17]. Worldwide, flood events have caused the largest amount of deaths and property damage during the last decades [18]. In Europe, the annual average flood damage in the last two decades was about $€ 4$ billion per year [19]. In the Mediterranean countries, floods tend to be greater in magnitude compared to the inner continental countries, and they frequently cause catastrophic damages [20].

Flood occurrence can be estimated in space and time through a sound basis of knowledge acquired by the scientific use of a large number of historical documents [21]. It is possible to gather useful information about historical floods that occurred during a period ranging from 1-2 centuries by using historical data [22]. Payrastre et al. [21] used discharges of historical floods that occurred during a period ranging from 1-2 centuries in four watersheds of the French Mediterranean area. They estimated the flood peak discharges and the associated low and high bound of its possible values for the main floods of each studied area. Historic data are useful for floodplain management, flood insurance rating, emergency planning and flood risk management. A careful search for data and their suitable arrangement may result in a powerful tool for flood disaster prevention and land use planning [23-25].

One essential step in any flood hazard analysis and estimation is the flood hazard recognition. This statement includes the record of possible geomorphologic evidence of flood activity, historic accounts and records [26]. Hydrologic models using time series flood data can be applied to assess flood peaks, depths, volumes and to map flood hazard areas [27-31]. However, these methods require data that are often unavailable [32]. Alternatively, researchers have used historical documents and historic flood data to estimate flood hazard [22,33]. Tropeano et al. [22] analyzed historical documents for a statistical elaboration of the frequency of landslide and flood events in Northern Italy in the last five centuries. Diakakis et al. [33] used an extensive catalogue of flooding phenomena during the last 130 years to examine flood events in Greece. According to their statistical and spatial analysis, urban areas tend to present higher flood recurrence rates than mountainous and rural ones and an increasing trend in reported flood event numbers during the last few decades. Moreover, a diachronic appraisal of the landscape evolution throughout the study of old topographic maps may include information on ungauged historical floods and paleofloods [34,35]. Skilodimou et al. [35] used old topographic maps to investigate the causes of flooding generation in the southwestern coast of Attica in Greece. They proved that the former wetlands and the lagoon of the study area have been dried up and covered by buildings, causing flood occurrences.

This paper aims to provide recognition of flood hazard by using historic data in the drainage basin of Pinios (Peneus) River, in Thessaly, central Greece. For this purpose, a catalogue of historical flood events that have caused damages was studied. These data, along with old topographic maps and geomorphic parameters such as elevation, slope, aspect and slope curvature were evaluated to record the temporal and spatial distribution of flood events of the study area. The analysis, processing and the evaluation of the old maps, geomorphic parameters and flood events were performed in a GIS environment. 


\section{Study Area}

The drainage basin of the study area is located in Thessaly, central Greece (Figure 1a), and it covers an area of about $11,200 \mathrm{~km}^{2}$. The elevations of the study area vary from 0-2678 $\mathrm{m}$ a.s.l. (Figure 1b). The hydrologic basin is drained by Pinios River, which has an approximate length of $205 \mathrm{~km}$. It is the third longest river in Greece and crosses a large part of the eastern part of central Greece discharging into the Aegean Sea, where it forms a delta.

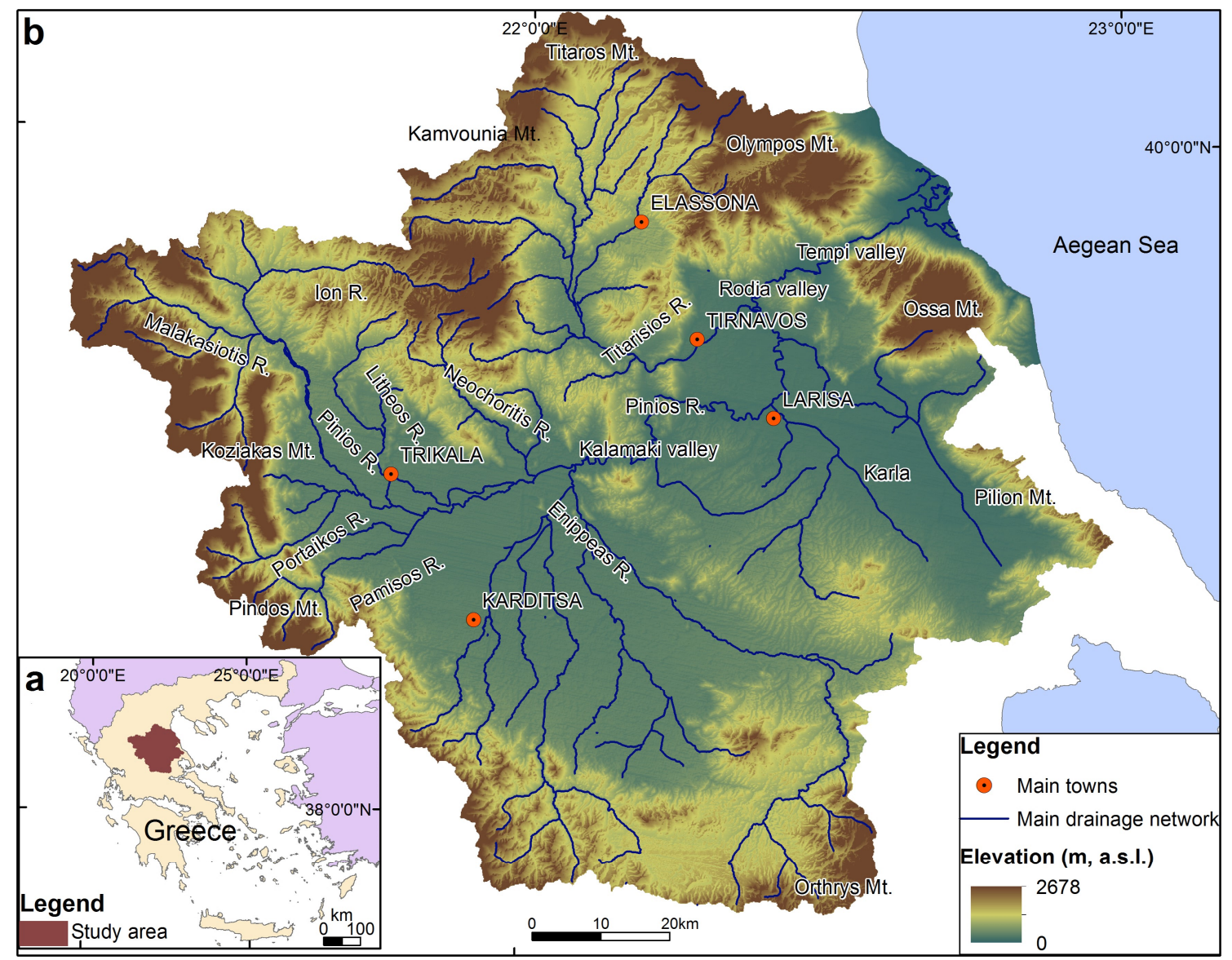

Figure 1. (a) Location map of the study area; (b) the elevations of the study area, the drainage network, the road network and the main settlements (modified from [36]).

Its course starts at the northwestern part of the Thessaly plain, from the confluence of the Ion and Malakasiotis rivers. It is surrounded by mountainous areas, which enclose its drainage basin and form its watershed (Figure 1b). To the north are the Titaros Mt. (1837 m) and the Kamvounia Mt. $(1615 \mathrm{~m})$; to the northeast are the Olympos Mt. (2917 m) and the Ossa Mt. (1978 m); to the east is the Pilio Mt. (1548 m); to the south is the Orthrys Mt. (1726 m); and finally, to the west are the Pindos Mt. (2204 m) and the Koziakas Mt. (1901 m).

The major tributaries of Pinios River are the Malakasiotis, Portaikos, Pamisos and Enippeas rivers to the west and south and the Ion, Lithaios, Neochoritis and Titarisios rivers to the north, which all drain large, heterogeneous areas, through extensive hydrographic networks (Figure 1b).

The plain area crossed by Pinios River is divided by the presence of a low-lying hill area into two parts (Figure 1b): (a) a western part (Trikala-Karditsa), whose altitude varies between 80 and $200 \mathrm{~m}$, and (b) an eastern part (Larisa), whose altitude varies between 45 and $100 \mathrm{~m}$. The mountainous and hilly area crossed by Pinios River has a quite rugged surface with altitudes exceeding $200 \mathrm{~m}$. The most important gorges are the ones of Kalamaki (internal low-lying hill area), Rodia and Tempi (between Olympos and Ossa). Through these areas, the water flow velocity is high, while erosion is 
intense. All the above, in conjunction with the fertility of the plain areas, necessitated the construction of drainage and irrigation projects.

Fifty five percent (55\%) of the study is mainly rural, semi-urban area. Irrigated agricultural land comprises $56 \%$ of the total cultivated area in the basin. The intense and extensive cultivation has led to a remarkable water demand increase, which is usually covered by the over-exploitation of groundwater resources [37].

The climate in the western and central side of the drainage basin of Pinios River is continental with cold winters and hot summers with a large temperature difference. The coastal area of the basin has a typical Mediterranean climate. Summers in the study area are usually very hot and dry, and in July and August, temperatures can reach up to $40{ }^{\circ} \mathrm{C}$. The mean annual precipitation over the basin is about $779 \mathrm{~mm}$. Rainfall is distributed unevenly in space, and it varies from about $360 \mathrm{~mm}$ at the eastern part of the basin to more than $1850 \mathrm{~mm}$ at the western mountain peaks. Generally, the rainiest months are November and December, while rainfall is rare from June-August. The mountain areas receive significant amounts of snow during the winter months. The mean annual total flow of the river is $3500 \times 10^{6} \mathrm{~m}^{3}$. The hydrologic regime of the river is affected by both winter rainfalls and spring snowmelt. The river flow regime at the main stem is perennial. The mean average flow near its delta ranges from more than $150 \mathrm{~m}^{3} / \mathrm{s}$ in February and March to about $10 \mathrm{~m}^{3} / \mathrm{s}$ in August and September. The water of Pinios River is used primarily for irrigation [37,38].

The Pinios River crosses alpine formations of various units and post-alpine formations. More specifically, the alpine formations at its western part belong to the Koziakas unit, at the central part to the Sub-Pelagonian and Pelagonian units and at its eastern part to the Pelagonian and Olympos-Ossa units. At the western sub-basin, a great part of its length passes through molassic formations of the Meso-Hellenic trough (Eocene-Pliocene) and Quaternary formations, while at the eastern part, it crosses mostly Neogene and Quaternary formations. The permeable rocks and sediments of the study area are divided into two major units, the karstic one consisting of carbonate formations (limestones, marbles and dolomites) and the granule materials, which include Neocene and Quaternary sediments. Semi-permeable formations are comprised of loose to semi-coherent Quaternary and Neocene deposits along with thin-bedded limestones and ophiolites. Impermeable formations consist of schists and fine-grained Quaternary and Neocene deposits [39-41].

The plain of Thessaly has suffered from flooding since ancient times, when several structures had been constructed in order to control the Pinios River 2500 years ago. Today, despite the construction of flood protection works, floods remain an important problem of the area [42].

\section{Materials and Methods}

\subsection{Data}

In the present study, the historical flood database of Greece was used [43]. It refers to floods that occurred during the period 1979-2010. This database was required by the Directive 2007/60/EC concerning floods in Europe. In Article 4 of the Directive 2007/60/EC, the construction of a historic flood data database is assigned to every state-member as a part of the preliminary assessment of flood risk, as well as finding the sensitive to flooding areas in each country, for the database will be used for the construction of flood risk maps [44]. The database contains information such as the location of flood (county and village or locality), geographical details, dates of occurrence, characteristics of the flood (e.g., flash flood, snow melt flood, etc.), the sources of flooding (e.g., pluvial, fluvial, groundwater, etc.), the causes of flooding, the mechanism of the flood, the extent of flooded area (in $\mathrm{km}^{2}$ ), the maximum distance of the flood (in $\mathrm{km}$ ), the type of damages, the total cost of the damage caused by the flood event, the number of human casualties and the class of the total damage caused by the flood (very high, high, medium or low).

Four old topographic maps of 1881 with the scale 1:200,000 were used in the current work. The used sheets are: Ioannina-Metsovon-Grevena-Kozani-Servia [45], Larissa-Elasson-Katerini [46], 
Arta-Trikala-Karditsa [47] and Volos-Farsalos-Lamia [48]. Figure 2 shows a mosaic of the four old topographic maps used.

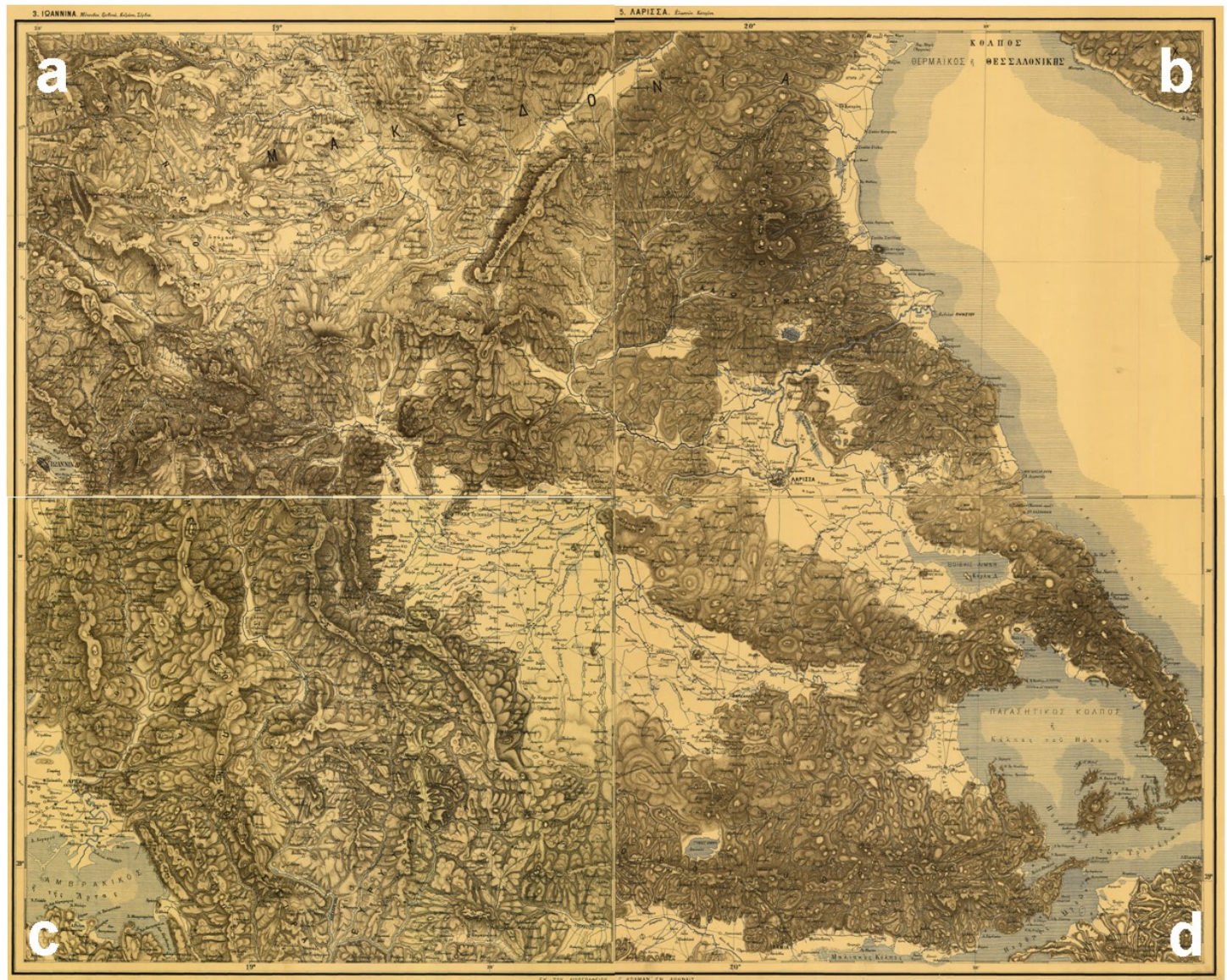

Figure 2. Old topographic maps of 1881, sheets: (a) Ioannina-Metsovon-Grevena-Kozani-Servia;

(b) Larissa-Elasson-Katerini; (c) Arta-Trikala-Karditsa; (d) Volos-Farsalos-Lamia.

Finally, thematic maps were used. These maps are the digital elevation model (DEM) of the study area, which is presented in Figure 1 and the geological map of the study area. They were acquired from previous work [36]. The DEM map was used to produce the elevation, slope, aspect and slope curvature maps. The geological map of the study area was used to identify the semi-permeable and impermeable formations of the study area.

\subsection{Statistical Analyses}

Several works have used historic flood data to analyze flood frequency, flood peak discharges and estimate flood hazard maps $[21,27,29,30]$. This kind of flood frequency analysis requires hydro-climatic data, such as flow and rainfall. In many cases, this is difficult to do, because detailed data are unavailable. On the other hand, researchers have analyzed the temporal and spatial distribution of floods based on the count of events [22,33]. The scope of the present work is to recognize flood hazard and examine the temporal and spatial distribution of flood events in the study area, rather than to create a flood hazard map. Additionally, high resolution data such as discharge or rainfall during flood events were not readily available. For these reasons, the statistical analysis depends on the location of floods, dates of occurrences, the flooded area, the type of damages and the total damage caused by the floods.

For the description and assessment of historical floods, information was sourced from various national and regional authorities, scientific reports and newspaper articles. In general, the accuracy of the data used was considered acceptable as multiple checks between different sources were carried out 
to ensure consistency of the data. The location of events shows some uncertainty. According to [49], when there was no reference to a particular community, but the geographical determination was different (i.e., reference to river or torrent), location was determined on the basis of the other descriptive information. Thus, in some cases, as an event location is given the center of the municipal department. The historic database includes information about the causes of flooding, the flood mechanism and characteristics along with the maximum distance of the flood. The data of these records were not systematic and accurate, and they were not taken into account in the present work.

As a first step, a temporal statistical analysis was performed to identify the number of events and flooded area distribution during this period. The statistical significance of these variables was tested by $p$-values. Additionally, to identify the seasonal distribution of flood events, these parameters were analyzed for each month.

Flood events that occurred in the study area had adverse consequences and caused damages to economic activity. The type of damage was categorized into three categories: economic (positions of infrastructures, industrial and commercial centers), rural land use (positions of farmland with significant economic value production) and property [49]. The distributions of the number of each type of damage from 1979-2010 along with their monthly distribution were examined.

The total damages caused by the floods were categorized into five classes taking into account the number of human casualties, amount of monetary compensation (state compensation for damages to agriculture and for damages to settlements) or the size of flooded area [50]. The classes of the total damage and the limits of the above-mentioned parameters are presented in Table 1.

Table 1. Categories of the total damages, amount of monetary compensation and flooded area of the historical flood events.

\begin{tabular}{cccc}
\hline Classes of Total Damages & Human Casualties & Compensation (Euro) & Flooded Area (Hectares) \\
\hline Low & $<50,000$ & $<200$ \\
Medium & $50,000-200,000$ & $200-500$ \\
High & $\geq 1$ & $200,000-500,000$ & $500-1000$ \\
Very High & $>500,000$ & $>1000$ \\
\hline
\end{tabular}

The annual and monthly distributions of the two above-mentioned parameters were studied during the period 1979-2010.

\subsection{Spatial Analyses}

Furthermore, a spatial analysis of the flood occurrences was carried out. The study area was divided into seven individual drainage basins. The spatial distribution of flood events in each drainage basin was examined. A spatial database was created, and ArcGIS 10.3 software was used to process the collected data.

Old maps may describe or simply locate areas that have flooded in the past. In many cases, former wetlands and lagoons that have been dried up cause flood events. Thus, the study of old topographic maps is very helpful to examine the causes of flood genesis [22,34,35]. The comparative observation of the old topographic maps of 1881 and the recent topographic maps of the study area led to a mapping of the previous wetlands. Marshy areas and lakes were digitized from the older edition survey maps, and they compared with the spatial distribution of current flood events. Finally, bibliographic data [36] were used to examine the association of the paleo-environment of Pinios River with the spatial frequency of floods.

The geomorphological setting of an area affects flood occurrences. Lowland morphology, gentle slopes and the flat areas create favorable conditions for flooding [51]. For this reason, the elevation, slope, aspect and slope curvature of the study area were examined. The selection of these geomorphological parameters and the determination of the class numbers, as well as their boundary values was based on the literature [51-54]. The elevation map was classified into two 
categories: (i) $<100 \mathrm{~m}$ and (ii) $>100 \mathrm{~m}$. Similarly, the slope was divided into two categories: (i) $<5^{\circ}$ and (ii) $>5^{\circ}$. The aspect map shows the slope direction and identifies the flat areas that have values $=-1^{\circ}$. Thus, the aspect map was categorized into two classes: (i) $=-1^{\circ}$ and (ii) $>-1^{\circ}$. In the case of curvature, negative curvatures represent concave, zero curvature represents flat and positive curvatures represent convex, respectively. Figure 3 shows the elevation, slope, aspect and the curvature maps and their categories. The areas with elevation $<100 \mathrm{~m}$, slope $<5^{\circ}$, aspect $=-1^{\circ}$ and curvature $=0$ were combined to identify the lowest and flattest areas of the study area. This was accomplished by the intersection tool of ArcGIS 10.3.

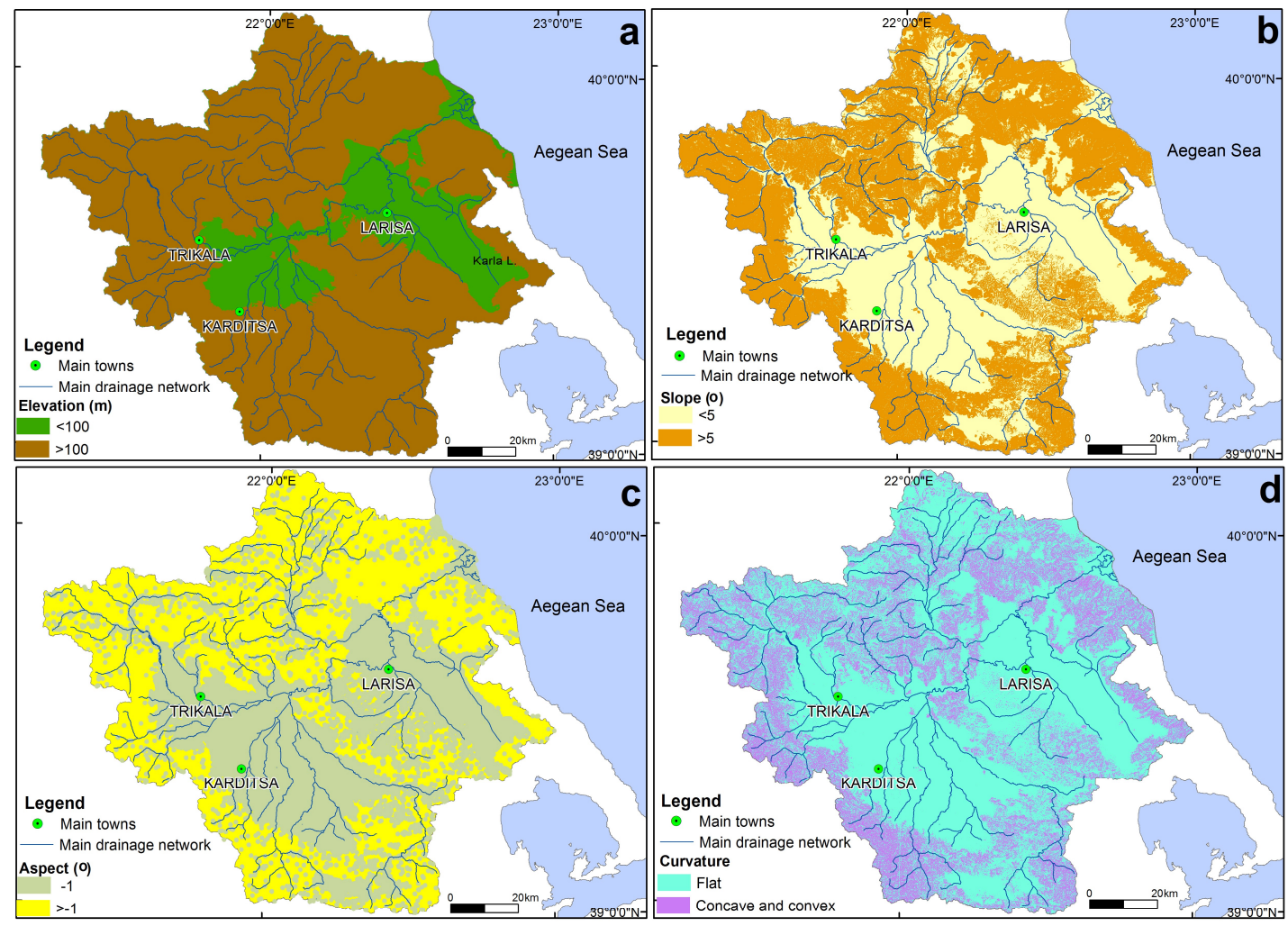

Figure 3. Thematic maps of the four geomorphological parameters: (a) elevation; (b) slope; (c) aspect; (d) curvature.

\section{Results}

\subsection{Temporal Distribution of Flood Events}

A total number of 146 flood events were recorded in the drainage basin of Pinios River during the period 1979-2010. Figure 4 shows the temporal distribution of flood occurrences during this period.

The number of flood events reached its maximum value (38) in 1994. The value of flood events was high (36) in the year 1987 and was relatively high (19) in 2002. In 1994, flood events were two-times higher than in 2002. In the 1980s, a total number of 40 flood events were recorded, while in the 1990s and 2000s, 55 and 47 were observed, respectively. Thus, there was a trend of increasing flood occurrences over the last two decades. The statistical analysis of the number of events showed that $p=0.009$. Thus, the data used have values $p<0.05$ and are statistically significant.

Figure 5 presents the seasonal distribution of flood events. The statistical analysis proved that October contained the most flood events (42). High values of flood occurrences were observed in March (35), in June (11) and in November (10). In October, the number of flood events was four-times higher than in June and November. 


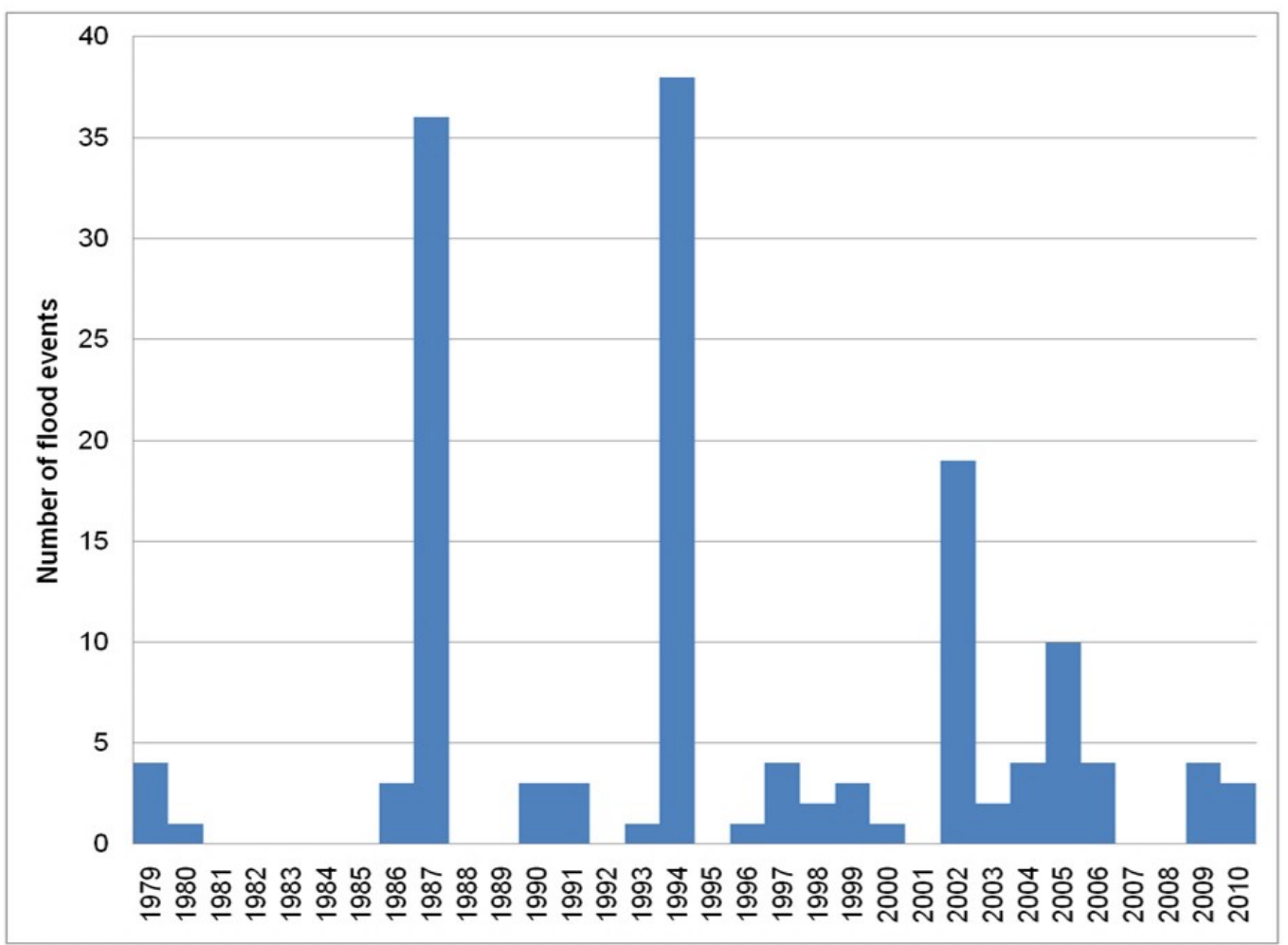

Figure 4. The annual distribution of flood events from 1979-2010.

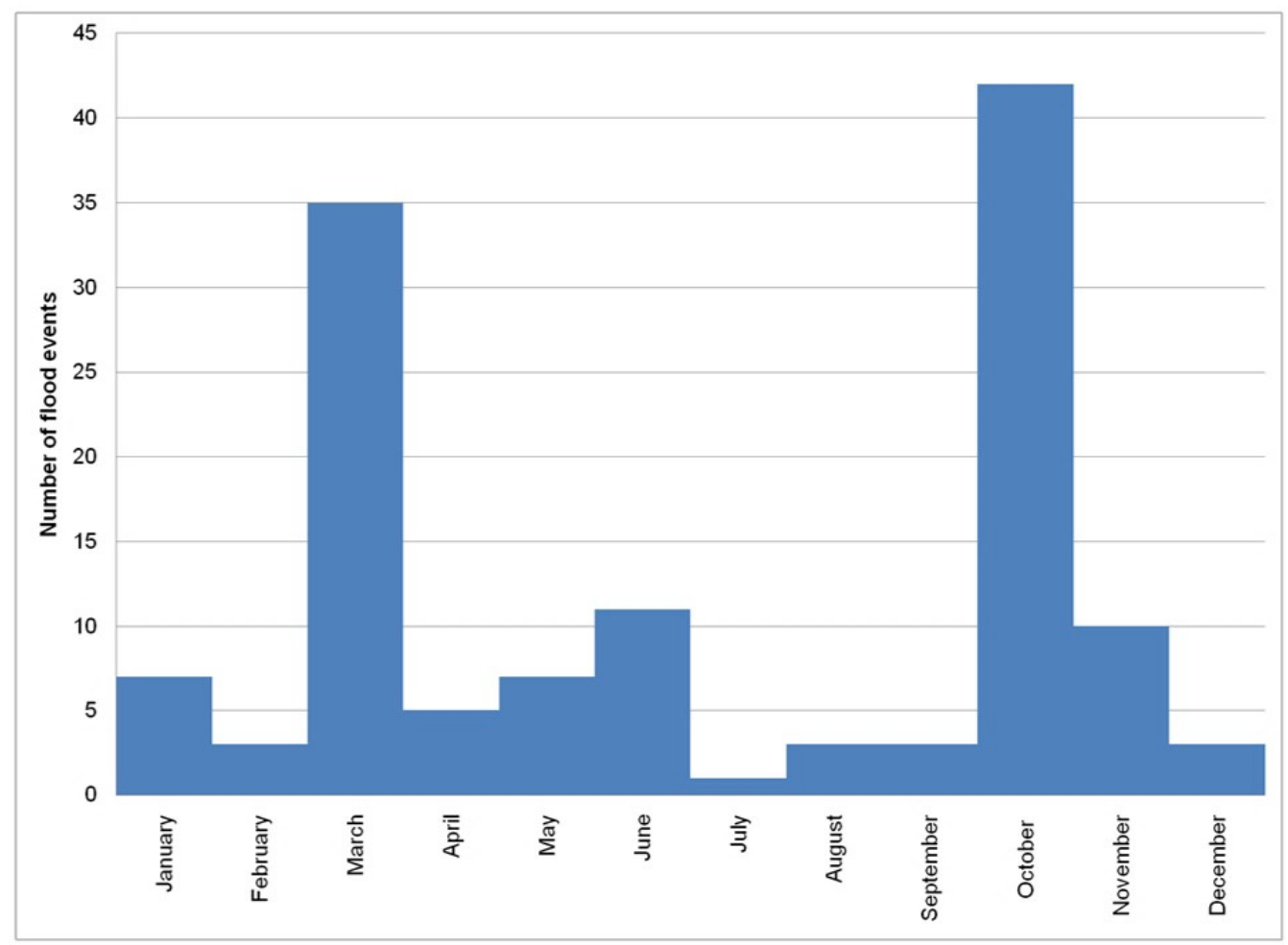

Figure 5. The monthly distribution of flood events during 1979-2010.

On the other hand, substantial differences appeared in the temporal distribution of the flooded area (Figure 6). It reached its maximum value $\left(87.4 \mathrm{~km}^{2}\right)$ in 1987 . Additionally, relatively high values were calculated in the years $1994\left(69.5 \mathrm{~km}^{2}\right)$ and $1997\left(64.8 \mathrm{~km}^{2}\right)$. The $p$-value was found to be 0.01 , and thus, the data used were statistically significant. Regarding the seasonal distribution of flooded 
area (Figure 7), it reached its maximum value $\left(136.5 \mathrm{~km}^{2}\right)$ in November. It presented relatively high values in March $\left(83.2 \mathrm{~km}^{2}\right)$ and October $\left(73.1 \mathrm{~km}^{2}\right)$.

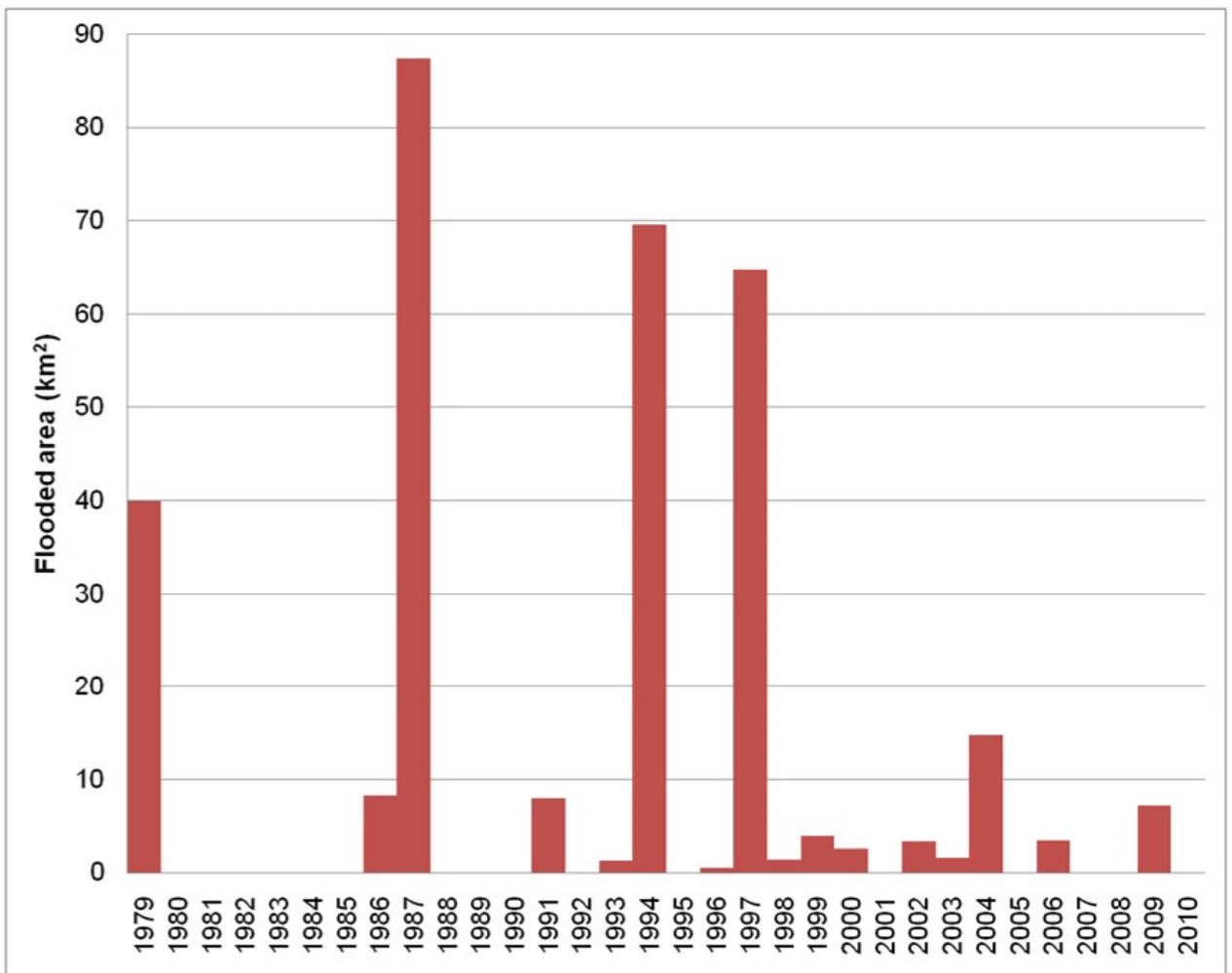

Figure 6. The monthly distribution of the flooded area during 1979-2010.

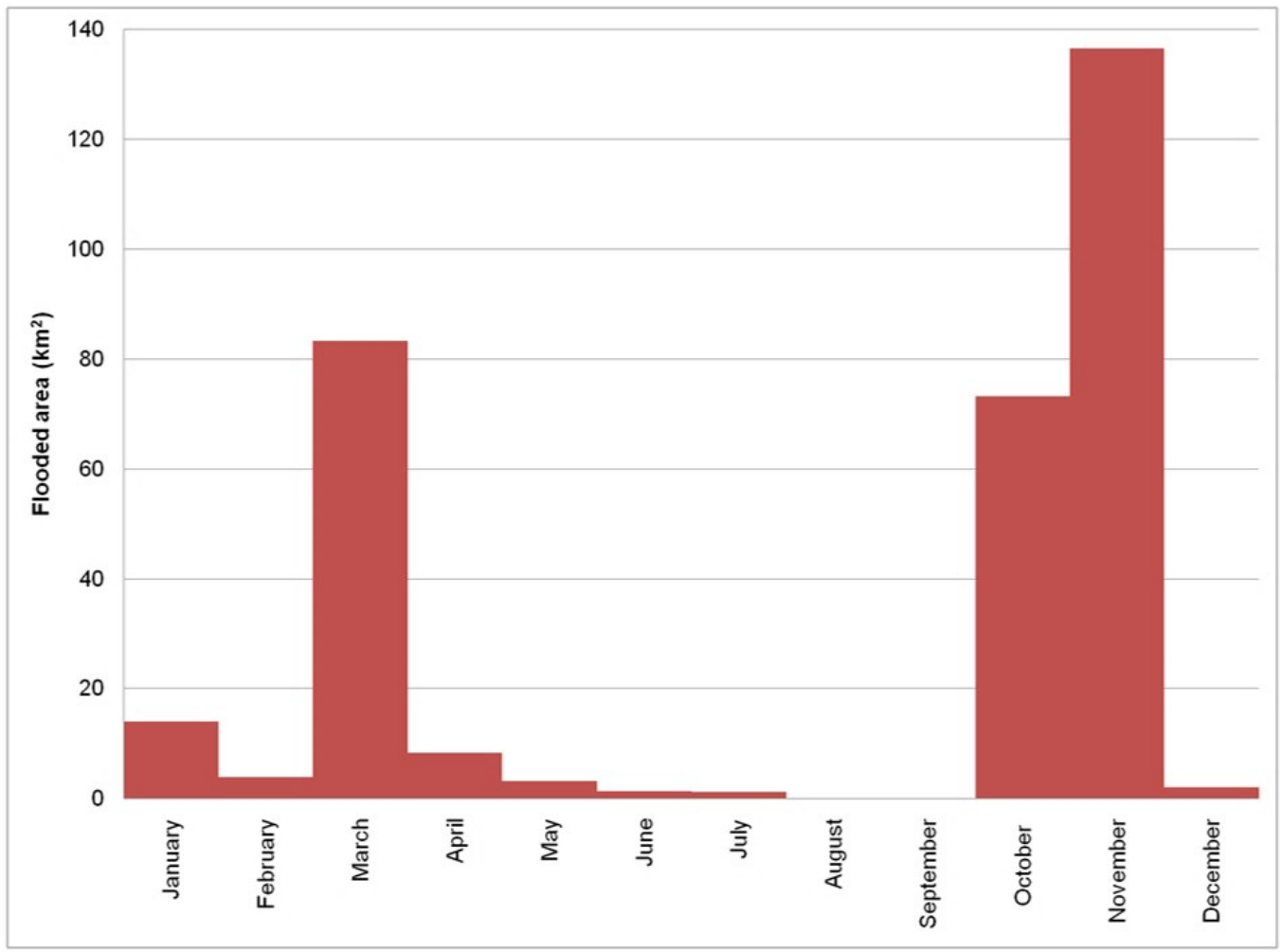

Figure 7. The monthly distribution of the flooded area during 1979-2010. 


\subsection{Temporal Distribution of Damages}

Concerning the type of damages, their temporal and seasonal distributions are presented, respectively, in Figures 8 and 9. It is important to note that no human casualties were observed during the studied period. The values of economic damages were low during the studied period and reached the maximum value (3) in the years 1987, 1990 and 2010 (Figure 8). Similarly, their monthly distributions had relatively low values. The maximum value (4) of economic damages was recorded in March (Figure 9).

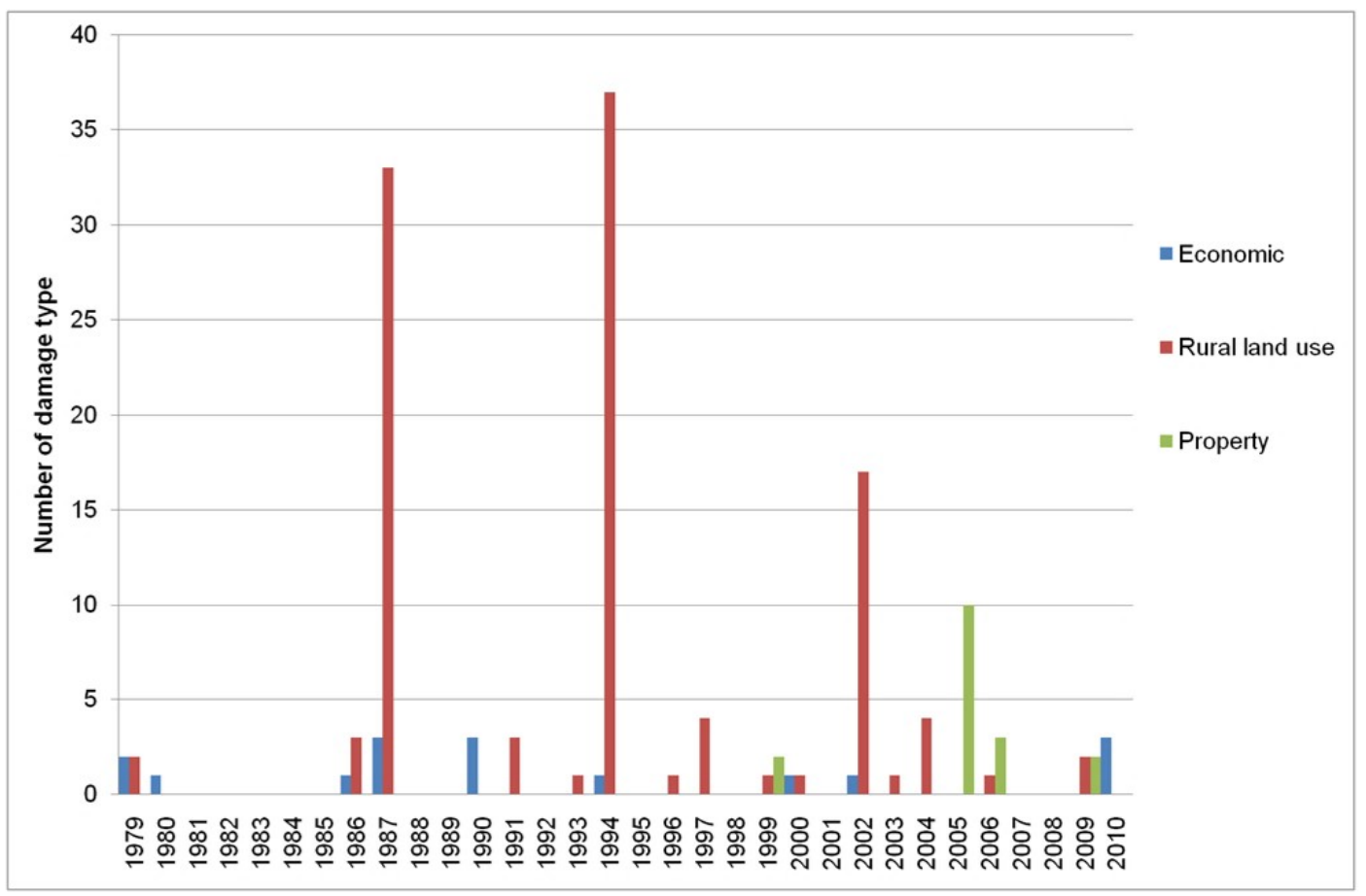

Figure 8. The annual distribution of type of damages in the study area during 1979-2010.

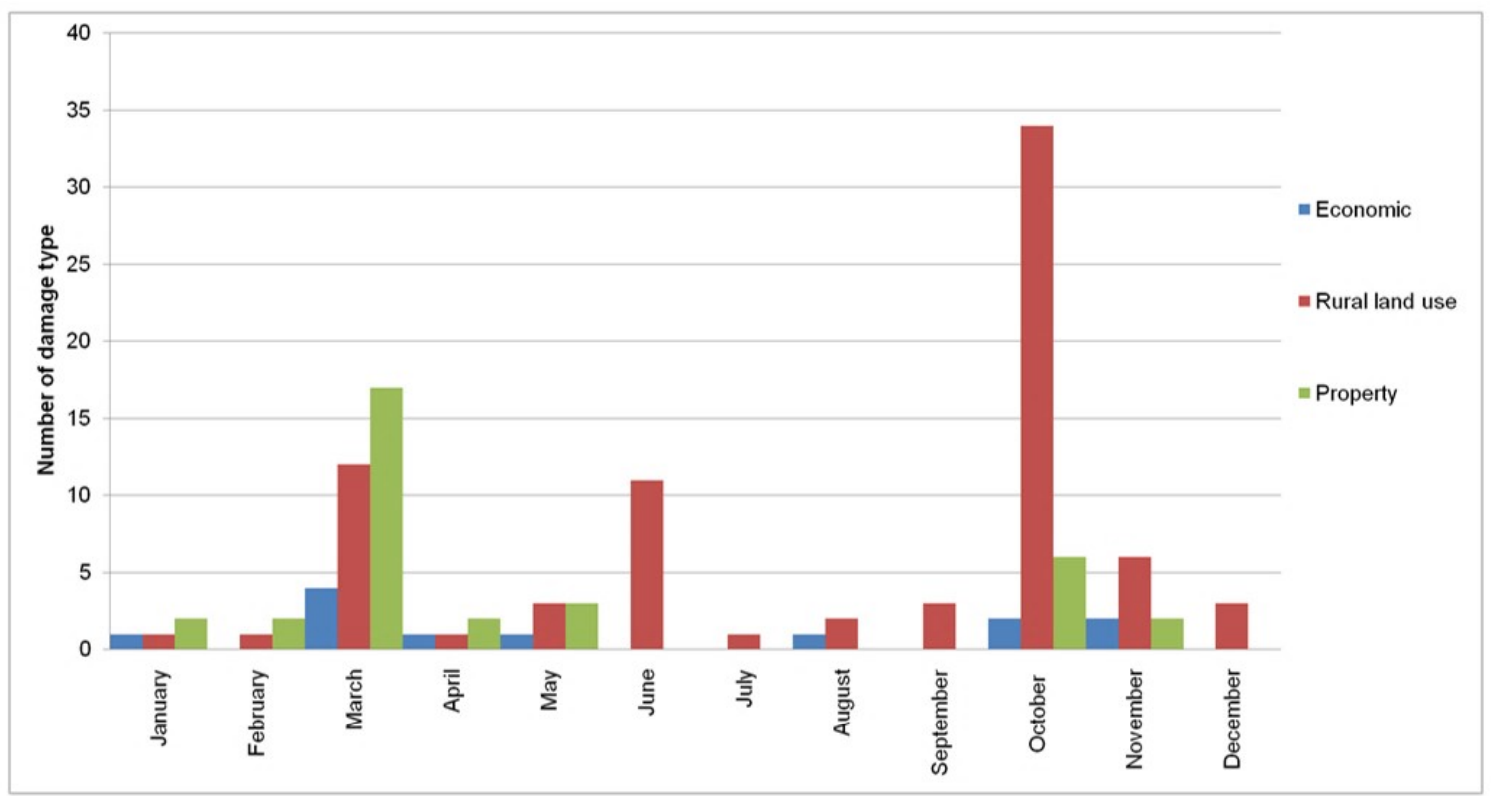

Figure 9. The monthly distribution of the type of damage. 
On the contrary, the values of rural land use were the highest among all the types of damages (Figure 8). It reached its maximum value (37) in 1994, while it had relatively high values in the years 1987 (33) and 2002 (17). October was the month with the most records (34) in this type of damage (Figure 9). Additionally, high values were observed in March (12) and June (11). The maximum value (10) of the property damages was recorded in 2005 (Figure 8). March included the most number of property damages (17), while relatively high values (Figure 9) were recorded in October (six).

Figures 10 and 11 show the temporal and monthly distribution of categories of damages in the study area. The maximum value (10) of the very high category was observed in 2005, whilst its relatively high values were recorded in the years 1979 (three) and 1987 (three). Moreover, this category reached its maximum value (10) in June; a relatively high value (four) was calculated in November. The high class of damages reached its maximum value (six) in 1987 and a relatively high value (three) in the year 1994. March contained most records (five) of this class, and a high value was computed in October. The medium class reached its maximum value (24) in 1994, and a high value (12) was observed in 1987. The month with the most records (28) of this class was October; while a high value (13) was calculated in March. The annual and monthly maximum values of the low damages were observed in the year 1987 (14) and in March (13). Finally, the maximum value of the unknown class was recorded in the year 2002 (17).

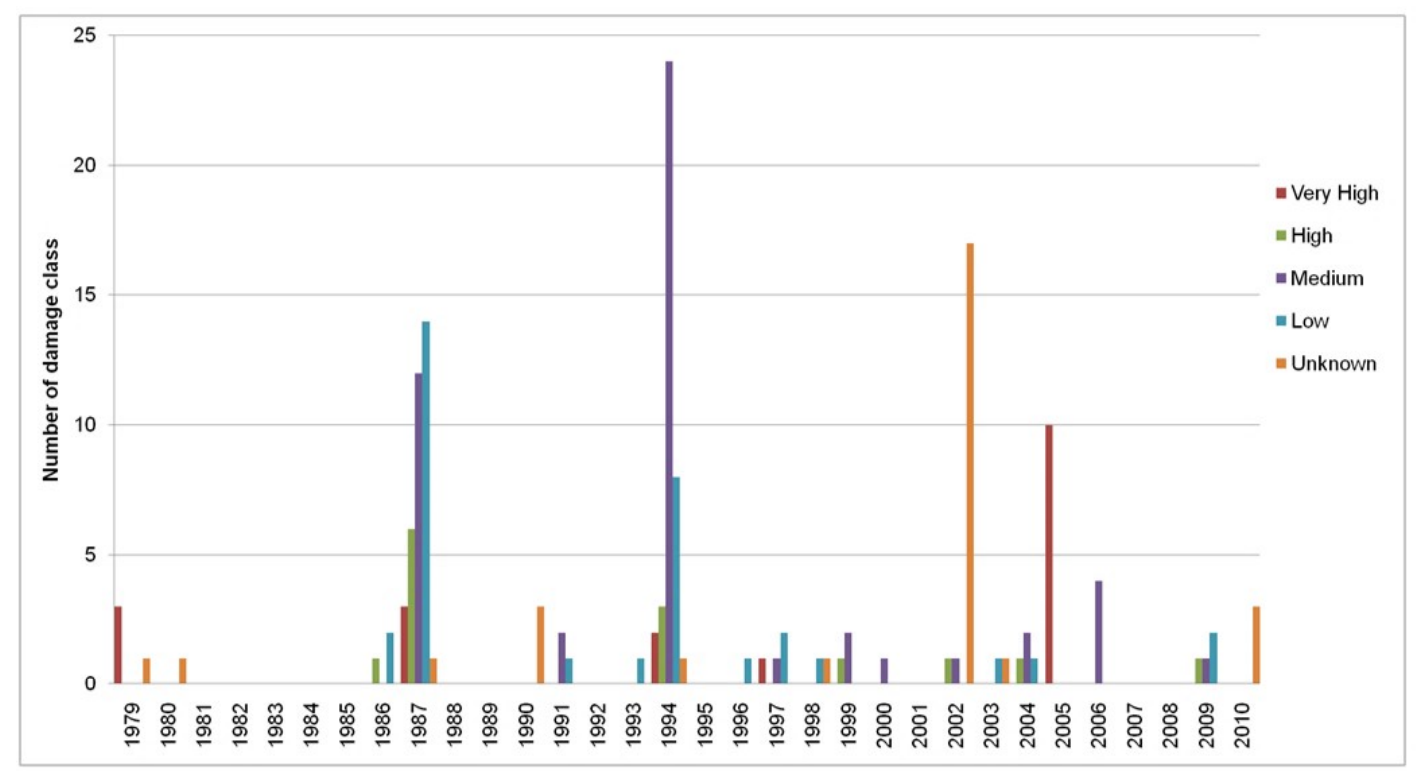

Figure 10. The annual distribution of categories of damages in the study area during 1979-2010. 


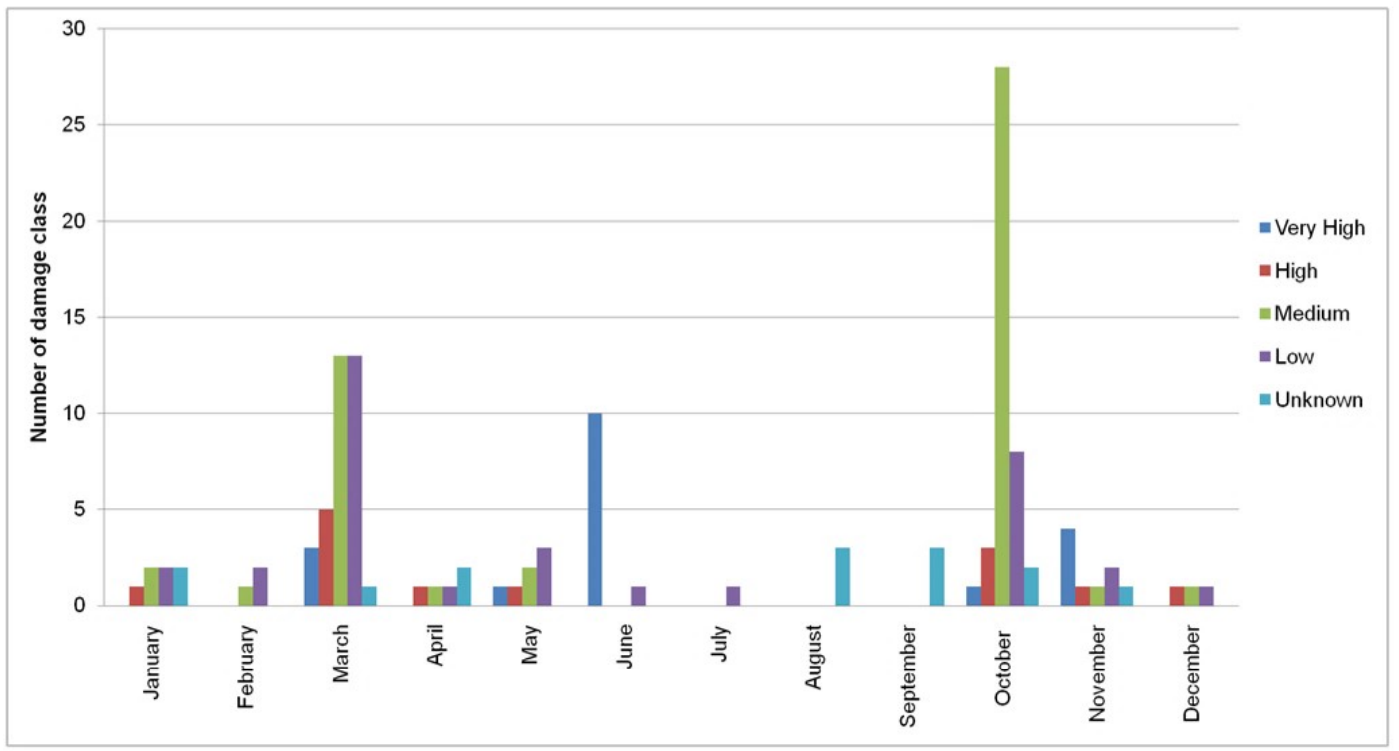

Figure 11. The monthly distribution of categories of damages during 1979-2010.

\subsection{Spatial Distribution of Flood Events}

The drainage basin of Pinios River were divided into seven sub-basins, which were: (a) the upper reaches of Pinios River; (b) Trikala-Neochoritis River; (c) Karditsa-Enippeas River; (d) Larisa-Karla; (e) Tempi Valley; (f) Titarisios River; and (g) the lower reaches of Pinios River. The spatial distribution of flood events in each drainage basin was examined. Table 2 shows the spatial distribution of flood events expressed as the number of events per drainage basin during the studied period. The most of floods were located in the drainage basin of Karditsa-Enippeas River.

Table 2. Spatial distribution of flood occurrences in each drainage sub-basin of the study area during the period 1979-2010.

\begin{tabular}{lc}
\hline \multicolumn{1}{c}{ Sub-Basin } & Number of Floods \\
\hline Upper reaches of Pinios River & 4 \\
Trikala-Neochoritis River & 21 \\
Karditsa-Enippeas River & 63 \\
Larisa-Karla & 33 \\
Tempi Valley & 6 \\
Titarisios River & 7 \\
Lower reaches of Pinios River & 12 \\
\hline
\end{tabular}

The mapping of the marshy area and lakes of the study area was based on the topographic map of 1881. They covered an area of about $161 \mathrm{~km}^{2}$. Moreover, according to [36], two paleo-lakes existed in the study area during the Quaternary. The former marshy areas and lakes along with the boundaries of two paleo-lakes were compared with the historic flood events (Figure 12). 


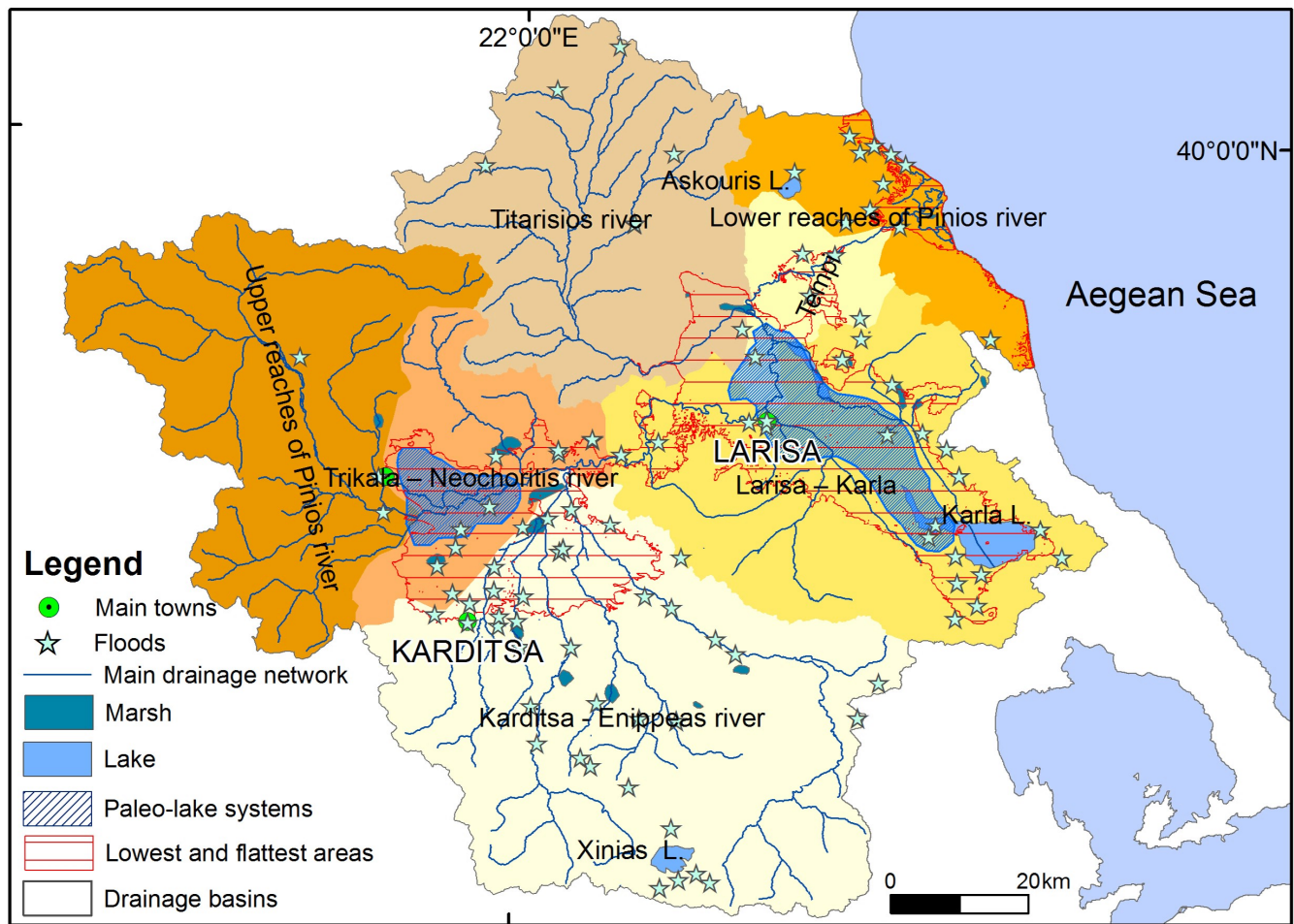

Figure 12. Marshy areas, lakes, paleo-lakes and lowest and flattest areas vs. flood occurrences in each drainage sub-basin of the study area during the period 1979-2010.

In the drainage basins of Trikala-Neochoritis River and Larisa-Karla, many flood events (12 events) were located in marshy areas, Lake Karla and paleo-lakes. In the drainage basin of Karditsa-Enippeas River, many floods (eight events) were located in or near marshy areas and Lake Xinias. In the drainage basins of Titarisios River and the lower reaches of Pinios River, few floods (two events) were located in or near marshy areas and Lake Askouris. Finally, in the drainage basins of the upper reaches of Pinios River and Tempi, no floods were associated with marshy areas.

The intersection of areas with an elevation $<100 \mathrm{~m}$, slope $<5^{\circ}$, aspect $=-1^{\circ}$ and curvature $=0$ is shown in Figure 12. The lowest and flattest areas were mainly located in the drainage basins of Trikala-Neochoritis River, Larisa-Karla and the lower reaches of Pinios River. In the drainage basins of Trikala-Neochoritis River and Larisa-Karla, they were mainly located in the areas where the former marshy areas and lakes were located. Regarding the spatial distribution of flood events, many flood events (61 events) were located in these areas.

\section{Discussion and Conclusions}

In the present study, the historical flood database of Greece and the old topographic maps of 1881 were used. These data were combined in a GIS environment to analyze the temporal and spatial distribution of flood events. The study area was the drainage basin of Pinios River, in Thessaly, central Greece.

The database contains floods that occurred between 1979 and 2010. A total number of 146 flood events were recorded in the drainage basin of Pinios River during this period.

The number of flood events reaches its maximum value (38) in the year 1994 (Figure 4). This may be related to flood events that occurred on 21-22 October 1994. No information about the causes of flooding, the flood mechanism and characteristics along with the maximum distance of the flood were included in the historic database. According to [55], this flood was caused by a severe storm. This intense storm caused flooding along the Pinios River and its tributaries, as well as inundation of agricultural and residential areas. 
The statistical analysis showed that the data used are statistically significant. The number of flood occurrences shows a rising trend during the period 1990-2010. The study of the monthly distribution of the events demonstrates that October contains the most flood events, while March is the second month with many flood records (Figure 5).

Regarding the flooded area, it reaches its maximum value $\left(87.4 \mathrm{~km}^{2}\right)$ in the year 1987 (Figure 6). This is attributed to flood event that occurred on 24-27 March 1987. The flood of March 1987 was caused by intense rainfall that produced direct runoff, as well as snowmelt. The water level of the Pinios River measured during the flood event exceeded $6.3 \mathrm{~m}$ in Kalamaki Valley and $8.0 \mathrm{~m}$ at Tempi Valley when the normal water level was less than $1 \mathrm{~m}$ in both locations (Figure 1b). Owing to the narrow riverbed at both locations (Kalamaki and Tempi), significant parts of the Thessaly plain upstream of each location were inundated [56].

Although October is the most flood-prone month, substantial differences appear in the monthly distribution of the flooded area. It reaches its maximum value $\left(136.5 \mathrm{~km}^{2}\right)$ in November (Figure 7). This difference may be related to several reasons such as the difference in storm characteristics.

In the study area, the economic damages have low values. The type of damage with the most records is the rural land use. The maximum value is recorded in the year 1994, while the month with the maximum value is October (Figures 8 and 9). According to [55], during the flood of 21-22 October 1994, more than 70 houses in about 20 communities were totally destroyed by the flood, more than 200 suffered severe damage and another 90 minor damage, whereas $80 \mathrm{~km}^{2}$ of agricultural land (cotton fields) were flooded. Concerning the property damages, the maximum value is observed in the year 2005, while March contains the most events (Figures 8 and 9). A flood event occurred in the study area on 16 June 2005, which caused serious damage to infrastructures and properties.

Regarding the class of damage, no human casualties were recorded in the study area between 1979 and 2010. According to [57], the most destructive events regarding human victims occurred in the city of Trikala in 1907. This flood caused at least 200 fatalities. Thus, the classification of the total damages is based on the amount of monetary compensation and flooded area of the historical flood events. The annual maximum value of the very high class is observed in the year 2005, while its monthly maximum value is recorded in June (Figures 10 and 11). This fact is related to the flood event of 16 June 2005. The amount of monetary compensation was 1,027,146 euros and was given for damages to infrastructures and properties [43]. The maximum value of the high class is recorded in the year 1987, and the maximum value of its monthly distribution is observed in March. This may be related to the flood event of 24-27 March 1987. Finally, the medium class has its maximum values in the year 1994 and in October, and this is related to the flood event of 21-22 October 1994.

The study area was divided into seven sub-basins to examine the spatial distribution of flood events (Table 2). The most occurrences are recorded in the southern part of the study area and specifically in the drainage basin of Karditsa-Enippeas River. Moreover, increased clustering of flood events is observed in the drainage basin of Larisa-Karla.

Old topographic maps of 1881 and bibliographic data were used to examine the relation of the paleo-environment of Pinios River with the spatial distribution of floods. The old topographic maps show earlier marshy areas and lakes, which nowadays, have dried up. According to [36], paleo-lake systems were located in the drainage basin of Pinios River during the Quaternary. One paleo-lake was located in the western part of the study area. Another, lower altitude paleo-lake, which was not connected to the previous one, was in the eastern part. During the Quaternary, the weathering of the carbonate rocks led to the connection of independent paleo-environments, and the Pinios River emerged. There is a certain amount of clustering of flood events in the areas of former marshes, lakes and paleo-lakes, which are located in the drainage basins of Trikala-Neochoritis River, Larisa-Karla and Karditsa-Enippeas (Figure 12).

In the study area, drainage and irrigation works along with levees were built 90 years ago, to protect it from flooding. However, incidents of annual flood events are reported in specific areas, and still, floods remain a big problem in the region [58]. Figure 12 presents the sites with earlier marshes 
and lakes, which are located in the lowest and flattest parts of the study area. The locations with earlier marshes and lakes are characterized by gentle slopes with low elevation and form the bottom of the drainage basin of the drainage network. These areas are developed mainly over semi-permeable or impermeable formations. The underlying geology and soil type affect the quality and the rate of infiltration. More specifically, the sediments within these wetlands may consist of materials such as clays and fine sands. These materials create a saturated layer on the surface during intense rainfall. Therefore, the specific runoff may be unable to further infiltrate the surface water into the subsurface. Consequently, these specific locations are sites where surface water runoff naturally collects and can lead to floods. Although, the wetlands and lakes have dried up, the morphology of the relief in these areas has not changed, causing flooding. According to studies carried out in other similar regions [35,52], the drainage basins that were $15 \%$ covered by wetlands had a flooding supply of 60-65\% more than those not bearing wetlands. Consequently, drying up of the marshy areas and lakes of the region has strongly favored the flood events in the drainage basin of Pinios River.

The low and flat areas are located in the central, south-eastern and coastal part of the study area (Figure 12), and they contain many flood events. Usually, when a flood occurs, the lowest and flattest areas will be flooded first. Thus, these locations are areas prone to flood. This lowland morphology of the plain and the narrow passages along the river course such as Kalamaki, Rodia and Tempi gorges are the main reasons for the flooding [58]. According to [55], other reasons favoring the flood genesis due to human activities are some bridges with inadequate heights that are across the river and the construction by the farmers of "handy" barriers in the river channel for storage of irrigation water.

Endogenic processes such as active tectonics of the study area probably will not affect the flooding hazard in the near future. On the other hand, exogenic processes such as climate changes are capable of influencing future flood occurrences. Possible climate changes will cause sea level rise. Different scenarios were produced by the Intergovernmental Panel on Climate Change (IPCC), which predicts sea level rise from 0.3 to about $1.0 \mathrm{~m}$ until 2100 [59]. The possible sea level rise will increase the flood risk in the coastal area of the study area.

The historic flood data and old topographic maps provide valuable information for land use planning at a regional scale, leading to the determination of the safe and non-safe areas for urban activities [60]. The proposed methodology estimates the localization of sites prone to flood, and it may be utilized for flood hazard assessment mapping and for flood risk management. In areas prone to flooding, the appropriate land use planning along with the selection of the proper constructions are essential to prevent and mitigate the consequences of flood hazard occurrence. Consequently, proper land use for specific areas (i.e., parks, residential areas, etc.) may be determined. Additionally, construction of flood control works such as dams and levees, ponds, lakes and lagoons may be selected. Thus, planners, engineers and policy makers may use the applied approach for new and existing land use planning projects and for floodplain management.

Author Contributions: G.D.B conceived of the research. H.D.S. and G.D.B. designed the research and the data analysis. K.S. prepared and analyzed the data. G.D.B., H.D.S., K.S. and E.K completed the field work. H.D.S. and E.K. created the figures. G.D.B and H.D.S. wrote the paper.

Funding: This research received no external funding.

Conflicts of Interest: The authors declare no conflict of interest.

\section{References}

1. Cerdà, A. Effect of Climate on Surface Flow along a Climatological Gradient in Israel: A Field Rainfall Simulation Approach. J. Arid Environ. 1998, 38, 145-159. [CrossRef]

2. Bathrellos, G.D.; Skilodimou, H.D.; Maroukian, H. The spatial distribution of Middle and Late Pleistocene cirques in Greece. Geogr. Ann. A 2014, 96, 323-338. [CrossRef]

3. Skilodimou, H.D.; Bathrellos, G.D.; Maroukian, H.; Gaki-Papanastassiou, K. Late Quaternary evolution of the lower reaches of Ziliana stream in south Mt. Olympus (Greece). Geogr. Fis. Din. Quat. 2014, 37, 43-50. [CrossRef] 
4. Bathrellos, G.D.; Skilodimou, H.D.; Maroukian, H.; Gaki-Papanastassiou, K.; Kouli, K.; Tsourou, T.; Tsaparas, N. Pleistocene glacial and lacustrine activity in the southern part of Mount Olympus (central Greece). Area 2017, 49, 137-147. [CrossRef]

5. Kamberis, E.; Bathrellos, G.; Kokinou, E.; Skilodimou, H. Correlation between the structural pattern and the development of the hydrographic network in a portion of the Western Thessaly basin (Greece). Cent. Eur. J. Geosci. 2012, 4, 416-424. [CrossRef]

6. Kokinou, E.; Skilodimou, H.D.; Bathrellos, G.D.; Antonarakou, A.; Kamberis, E. Morphotectonic analysis, structural evolution/pattern of a contractional ridge: Giouchtas Mt., Central Crete, Greece. J. Earth Syst. Sci. 2015, 124, 587-602. [CrossRef]

7. Chousianitis, K.; Del Gaudio, V.; Sabatakakis, N.; Kavoura, K.; Drakatos, G.; Bathrellos, G.D.; Skilodimou, H.D. Assessment of Earthquake-Induced Landslide Hazard in Greece: From Arias Intensity to Spatial Distribution of Slope Resistance Demand. Bull. Seismol. Soc. Am. 2016, 106, 174-188. [CrossRef]

8. Bathrellos, G.D.; Skilodimou, H.D.; Maroukian, H. The significance of tectonism in the glaciations of Greece. Geol. Soc. Spé;c. Publ. 2017, 433, 237-250. [CrossRef]

9. Papadopoulou-Vrynioti, K.; Bathrellos, G.D.; Skilodimou, H.D.; Kaviris, G.; Makropoulos, K. Karst collapse susceptibility mapping considering peak ground acceleration in a rapidly growing urban area. Eng. Geol. 2013, 158, 77-88. [CrossRef]

10. Tsolaki-Fiaka, S.; Bathrellos, G.D.; Skilodimou, H.D. Multi-criteria decision analysis for abandoned quarry restoration in Evros Region (NE Greece). Land 2018, 7, 43. [CrossRef]

11. Skilodimou, H.D.; Bathrellos, G.D.; Koskeridou, E.; Soukis, K.; Rozos, D. Physical and anthropogenic factors related to landslide activity in the Northern Peloponnese, Greece. Land 2018, 7, 85. [CrossRef]

12. Morisawa, M. Geomorphology Laboratory Manual; Willey \& Sons: Hoboken, NJ, USA, 1976; 253p.

13. Slaymaker, O. Geomorphic Hazards; John Wiley \& Sons: Hoboken, NJ, USA, 1997; 204p.

14. Bathrellos, G.D. An overview in Urban Geology and Urban Geomorphology. Bull. Geol. Soc. Greece 2007, 40, 1354-1364. [CrossRef]

15. Bathrellos, G.; Skilodimou, H. Geomorphic Hazards and Disasters. Bull. Geol. Soc. Greece 2006, 39, 96-103. (In Greek)

16. Goudie, S.A. Encyclopedia of Geomorphology; Goudie, S.A., Ed.; Taylor \& Francis Group: New York, NY, USA, 2006; pp. 378-379.

17. Merz, B.; Kreibich, H.; Schwarze, R.; Thieken, A. Assessment of economic flood damage. Nat. Hazards Earth Syst. Sci. 2010, 10, 1679-1724. [CrossRef]

18. CEOS. The Use of Earth Observing Satellites for Hazard Support: Assessments and Scenarios; Final Report of the CEOS Disaster Management Support Group (DMSG); CEOS: Rome, Italy, 2003.

19. European Environment Agency (EEA). Mapping the Impacts of Natural Hazards and Technological Accidents in Europe: An Overview of the Last Decade; Office for Official Publications of the European Communities: Luxembourg; European Environment Agency (EEA): Copenhagen, Denmark, 2010.

20. Gaume, E.; Bain, V.; Bernardara, P.; Newinger, O.; Barbuc, M. A compilation of data on European flash floods. J. Hydrol. 2009, 367, 70-78. [CrossRef]

21. Payrastre, O.; Gaume, E.; Andrieu, H. Use of historical data to assess the occurrence of floods in small watersheds in the French Mediterranean area. In Advances in Geosciences; European Geosciences Union: Munich, Germany, 2005; Volume 2, pp. 313-320.

22. Tropeano, D.; Turconi, L. Using historical documents for landslide, debris flow and stream flood prevention. Applications in Northern Italy. Nat. Hazards 2004, 31, 663-679. [CrossRef]

23. Van Alphen, J.; Martini, F.; Loat, R.; Slomp, R.; Passchier, R. Flood risk mapping in Europe, experiences and best practices. J. Flood Risk Manag. 2009, 2, 285-292. [CrossRef]

24. Rijal, S.; Rimal, B.; Sloan, S. Flood Hazard Mapping of a Rapidly Urbanizing City in the Foothills (Birendranagar, Surkhet) of Nepal. Land 2018, 7, 60. [CrossRef]

25. Samanta, S.; Koloa, C.; Kumar Pal, D.; Palsamanta, B. Flood Risk Analysis in Lower Part of Markham River Based on Multi-Criteria Decision Approach (MCDA). Hydrology 2016, 3, 29. [CrossRef]

26. Jakob, M. Debris flow hazard analysis. In Debris-Flow Hazards and Related Phenomena; Jakob, M., Hungr, O., Eds.; Springer: Berlin, Germany, 2005; p. 794.

27. Langbein, W.B. Annual floods and the partial-duration flood series. Trans. Am. Geophys. Union 1949, 30, 879-881. [CrossRef] 
28. Onyutha, C. On rigorous drought assessment using daily time scale: Non-stationary frequency analyses, revisited concepts, and a new method to yield non-parametric indices. Hydrology 2017, 4, 48. [CrossRef]

29. Lang, M.; Ouarda, T.B.M.J.; Bobée, B. Towards operational guidelines for over-threshold modeling. J. Hydrol. 1999, 225, 103-117. [CrossRef]

30. Willems, P. A time series tool to support the multi-criteria performance evaluation of rainfall-runoff models. Environ. Model. Softw. 2009, 24, 311-321. [CrossRef]

31. Smith, R.L. Threshold Methods for Sample Extremes. In Statistical Extremes and Applications; de Oliveira, J.T., Ed.; NATO ASI Series; Springer: Dordrecht, The Netherlands, 1985; Volume 131, pp. 623-638.

32. De Moel, H.; van Alphen, J.; Aerts, J.C.J.H. Flood maps in Europe-Methods, availability and use. Nat. Hazards Earth Syst. Sci. 2009, 9, 289-301. [CrossRef]

33. Diakakis, M.; Mavroulis, S.; Deligiannakis, G. Floods in Greece, a statistical and spatial approach. Nat. Hazards 2012, 62, 485-500. [CrossRef]

34. Skilodimou, H.; Stefouli, M.; Bathrellos, G. Spatio-temporal analysis of the coastline of Faliro Bay, Attica, Greece. Estud. Geol.-Madrid. 2002, 58, 87-93. [CrossRef]

35. Skilodimou, H.; Livaditis, G.; Bathrellos, G.; Verikiou-Papaspiridakou, E. Investigating the flooding events of the urban regions of Glyfada and Voula, Attica, Greece: A contribution to Urban Geomorphology. Geogr. Ann. A 2003, 85, 197-204. [CrossRef]

36. Migiros, G.; Bathrellos, G.; Skilodimou, H.; Karamousalis, T. Pinios (Peneus) River (Central Greece): Hydrological-geomorphological elements and changes during the quaternary. Cent. Eur. J. Geosci. 2011, 3, 215-228. [CrossRef]

37. Mylopoulos, N.; Kolokytha, E.; Loukas, A.; Mylopoulos, Y. Agricultural and water resources development in Thessaly, Greece in the framework of new European Union policies. Int. J. River Basin Manag. 2009, 7, 73-89. [CrossRef]

38. Goumas, K. The irrigation in Thessaly plain: Effects to underground and surface waters. In Proceedings of the Greek Hydrotechnical Association Conference, Larissa, Greece, 2 February 2006; pp. 39-53. (In Greek)

39. Katsikatsos, G.; Migiros, G.; Vidakis, M. La structure géologique de la région de la Théssalie orientale (Grèce). Ann. Soc. Géol. Nord 1982, CI, 177-188.

40. Migiros, G. The lithostratigraphic-tectonic structure of Orthris (Central Greece). Bull. Geol. Soc. Greece 1990, 26, 107-120. (In Greek)

41. Ferriere, J.; Reynaud, J.; Pavlopoulos, A.; Bonneau, M.; Migiros, G.; Proust, J.N.; Gardin, S. Geological evolution and geodynamic controls of Tertiary intramontane piggyback Meso-Hellenic Basin, Greece. Bull. Soc. Geol. Fr. 2004, 175, 361-381. [CrossRef]

42. Mimikou, M.; Koutsoyiannis, D. Extreme Floods in Greece: The Case of 1994. In Proceedings of the U.S.-Italy Research Workshop on the Hydrometeorology, Impacts and Management of Extreme Floods, Perugia, Italy, 13-17 November 1995.

43. Ministry of Environment and Energy. Special Secretariat for Water. Floods, Historic Floods. 2017. Available online: http:/ / www.ypeka.gr / Default.aspx?tabid=252\&locale=el-GR\&language=en-US (accessed on 17 June 2018).

44. European Commission. Directive 2007/60/EC of the European Parliament and of the Council on the Assessment and Management of Flood Risks; European Environment Agency: Copenhagen, Denmark, 2007.

45. Hrisohoou, M. Sheet "Ioannina-Metsovon-Grevena-Kozani-Servia"; Topographic Map, Scale 1:200,000; Colman George: Athens, Greece, 1881.

46. Hrisohoou, M. Sheet "Larissa-Elasson-Katerini"; Topographic Map, Scale 1:200,000; Colman George: Athens, Greece, 1881.

47. Hrisohoou, M. Sheet "Arta-Trikala-Karditsa"; Topographic Map, Scale 1:200,000; Colman George: Athens, Greece, 1881.

48. Hrisohoou, M. Sheet "Volos-Farsalos-Lamia"; Topographic Map, Scale 1:200,000; Colman George: Athens, Greece, 1881.

49. Ministry of Environment, Energy and Climate Change. Preliminary Flood Risk Assessment in Greece; Ministry of Environment and Energy: Athens, Greece, 2012. (In Greek)

50. Ministry of Environment and Energy. Special Secretariat for Water, Management Plan for the Drainage Basins of Eastern Peloponnese; Ministry of Environment and Energy: Athens, Greece, 2017. (In Greek) 
51. Bathrellos, G.D.; Skilodimou, H.D.; Chousianitis, K.; Youssef, A.M.; Pradhan, B. Suitability estimation for urban development using multi-hazard assessment map. Sci. Total Environ. 2017, 575, 119-134. [CrossRef] [PubMed]

52. Bathrellos, G.D.; Karymbalis, E.; Skilodimou, H.D.; Gaki-Papanastassiou, K.; Baltas, E.A. Urban flood hazard assessment in the basin of Athens Metropolitan city, Greece. Environ. Earth Sci. 2016, 75, 319. [CrossRef]

53. Rozos, D.; Bathrellos, G.D.; Skilodimou, H.D. Comparison of the implementation of Rock Engineering System (RES) and Analytic Hierarchy Process (AHP) methods, based on landslide susceptibility maps, compiled in GIS environment. A case study from the Eastern Achaia County of Peloponnesus, Greece. Environ. Earth Sci. 2011, 63, 49-63. [CrossRef]

54. Pradhan, B. Flood susceptible mapping and risk area delineation using logistic regression, GIS and remote sensing. J Spat. Hydrol. 2010, 9, 1-18.

55. Koutsoyiannis, D.; Mimikou, M. Management and Prevention of Crisis Situations: Floods, Droughts and Institutional Aspects; 3rd EURAQUA Technical Review; Country Paper for Greece: Rome, Italy, 1996; pp. 63-77.

56. Koukis, G.; Koutsoyiannis, D.; Embleton, C.; Embleton-Hamann, C. (Eds.) Geomorphological Hazards of Europe; Elsevier: New York, NY, USA, 1997; Volume 5, pp. 215-242.

57. Bathrellos, G. Geological, Geomorphological and Geographic Study of Urban Areas in Trikala Prefecture-Western Thessaly. Ph.D. Thesis, National \& Kapodistrian University of Athens, Athens, Greece, 2005; p. 561, (In Greek with Extended English Abstract).

58. Bathrellos, G.D.; Gaki-Papanastassiou, K.; Skilodimou, H.D.; Papanastassiou, D.; Chousianitis, K.G. Potential suitability for urban planning and industry development by using natural hazard maps and geological-Geomorphological parameters. Environ. Earth Sci. 2012, 66, 537-548. [CrossRef]

59. Intergovernmental Panel on Climate Change (IPCC). Climate Change 2014 Synthesis Report Summary for Policymakers, August 2018. Available online: https:/ / www.ipcc.ch/pdf/assessment-report/ar5/syr/AR5_ SYR_FINAL_SPM.pdf (accessed on 17 June 2018).

60. Bathrellos, G.D.; Gaki-Papanastassiou, K.; Skilodimou, H.D.; Skianis, G.A.; Chousianitis, K.G. Assessment of rural community and agricultural development using geomorphological-geological factors and GIS in the Trikala prefecture (Central Greece). Stoch. Environ. Res. Risk Assess. 2013, 27, 573-588. [CrossRef] 